\title{
Consumer acceptability and perceptions of maize meal in Giyani, South Africa
}

\author{
Teclah P Khumalo; Hettie C Schönfeldt \& Hester Vermeulen ${ }^{1}$
}

This study examined the acceptability and perceptions of traditionally prepared maize meal porridge, cooked from commercial roller-mill white maize meal and hammer-mill white and yellow maize meal (with and without fibre), among female Tsonga consumers in Giyani in Limpopo Province, South Africa. The study used sensory evaluation tests, followed by focus group discussions to gather supportive information about consumer attitudes, perceptions and practices regarding the consumption of maize meal porridge prepared from these maize meal types. Giyani consumers preferred commercial roller-mill white sifted fortified and white super-fortified maize meal, but, contrary to popular belief, were also willing to accept hammer-mill yellow maize meal, mainly for its nutritional value.

Keywords: maize meal porridge; sensory evaluation; perceptions; consumer acceptance

\section{Introduction}

Maize meal is South Africa's dominant staple food. Urban consumers and also many rural ones purchase commercially produced (roller-mill) maize meal from commercial mills, depots or retailers. In rural areas many consumers still grow white maize on their own plots on a small scale, to be milled at nearby village-based hammer mills for a fee (Traub \& Jayne, 2004:14).

White maize constitutes more than $90 \%$ of Africa's total maize crop production and about $33 \%$ of the world's white maize, while yellow maize is used mainly for animal feed. Genetically and chemically, white and yellow maize are virtually indistinguishable (McCann, 2005:111-12). However, yellow maize produced in sub-Saharan Africa has been found to be of higher nutritional value than white maize (Batán, 2003:2) as it contains traces of vitamin A in its seed coat.

There are three basic kinds of commercial roller-mill maize meal available in South Africa: 'super', which is highly refined and the most expensive, 'special' or medium refined and 'sifted', which is the least refined and least expensive (NDA, Regulation 1738:1993; Traub \& Jayne, 2004:6). In South Africa maize products must be clearly labelled indicating the name and address of the processor and the net mass of the product and its grade. The white grain is most commonly consumed and is preferred to the yellow grain. It is generally believed that the latter is mostly not accepted by South African consumers for maize porridge and is considered more suitable for stock feed. In addition, as from 7 October 2003, all manufacturers of maize meal have to fortify maize meal, in terms of the regulations

\footnotetext{
${ }^{1}$ Respectively, M Consumer Science Student, Department of Consumer Science, University of Pretoria; Professor, School of Agricultural and Food Sciences, University of Pretoria; and Researcher, Department of Agricultural Economics, Extensions and Rural Development, Faculty of Natural and Agricultural Sciences, University of Pretoria. Corresponding author: hester.vermeulen@up.ac.za
} 
pertaining to the fortification of foodstuffs under the Foodstuffs, Cosmetics and Disinfectants Act No. 54 of 1972 (NDA, 2006). The fortification mixture contains vitamin A, thiamin (vitamin B1), riboflavin (vitamin B2), niacin, folic acid, pyridoxine (vitamin B6), iron and zinc (DoH \& UNICEF South Africa, 2008:5). This is mostly done by medium-scale and large-scale production millers, using the guidelines of the Act.

The objective of the study was to investigate the acceptability and perceptions of traditionally prepared maize meal porridge, cooked from commercial roller-mill white maize meal (white sifted unfortified and fortified, and white super-fortified) and hammer-mill white and yellow maize meal (with and without fibre, i.e. the hulls of the maize grains) among Tsonga households in the Greater Giyani District Municipality, in the north west of Limpopo Province. The study formed part of a larger target project, 'Small-scale Millers in South Africa', funded partly by the National Research Foundation.

\section{Research method}

The study was conducted in two phases, using a variety of data collecting techniques (triangulation) in order to increase accuracy and minimise error. For Phase I, quantitative sensory evaluation tests were used (Meiselman, 1988:302; Lawless \& Heymann, 1998:2). Numerical data were collected and analysed in order to compare consumer acceptance of maize meal porridge prepared from commercial roller-mill white maize meal with hammermill white and yellow maize meal (with and without fibre). In Phase II, focus groups were used to gather information to support the findings of Phase I about consumer attitudes, perceptions and practices regarding the consumption of these maize meal types.

\subsection{Sampling}

A target population may be defined as that segment of the population that uses or is expected to use the product (Resurrection, 1998:71; Lawless \& Heymann, 1998:656). In this study they were Tsonga consumers, chosen as participants because of their role in purchasing and cooking food for the family. They were females, 18 years old or older, willing to participate, recruited by the local pastor in Giyani, who knows many of the community members and is familiar with the local language and customs. There were 21 participants from Homu 14A village and 27 from Mahlathi village, making a total of 48. The sampling procedure and size for this study was not designed to be representative (Furst et al., 1996:262) but was used to develop an initial understanding of the level of acceptability of commercial roller-mill white maize meal, as well as hammer-mill white and yellow maize meal porridge with and without fibre. Among the factors that limited the sample size were the cost (for travelling and materials), the small space available for preparing and cooking the porridge, and the time required for translating each procedure from English to the Xitsonga languageand checking each completed questionnaire, as the participants had limited reading and writing skills. The process took about six hours per day in each area, which is a considerable time commitment for women who have families to care for.

\subsection{Data collection for Phase I}

The study used a Likert scale offering four options: $1=$ dislike very much, $2=$ dislike moderately, 3 = like moderately, $4=$ like very much. To accommodate the respondents' limited reading and writing skills, each Likert scale option was represented by a simple 
picture of a face, ranging from an unhappy expression for 'dislike very much' to a very happy expression for 'like very much'. A four-point scale was used for simplicity, since the participants' literacy level was limited. The scale was pre-tested during a pilot study visit on a small sample of six participants in order to determine the functionality of the measuring instrument, as suggested by Resurrection (1998:30).

The evaluation area used for the sensory evaluation was the local church hall. It was clean and isolated from the cooking area to prevent diffusion of the smells (Lawless \& Heymann, 1998:86), since the smell of well-cooked or burnt starch from the maize meal could influence the participants positively or negatively and compromise the reliability of their responses to the detriment of the study.

During the pilot study the maize porridge recipes were standardised so that the quantity of ingredients, cooking methods and cooking time would remain consistent throughout the study, to ensure accurate data collection. Standardisation ensures food product control, making it possible to predict the quality and yield of the finished product (Reed \& Schuster, 2002:2). In both villages the cooking was done according to the local cooking techniques of Giyani by two local women who were familiar with technique. They were supervised by one student from the research team for the entire project, to ensure that standardised recipes were adhered to for the duration of the study, as a precaution against distortion of the results. The cooking method may have a strong effect on the acceptability of the porridge, since methods vary from region to region, so the porridge was prepared in the traditional manner specific to the area of study. The same local team was used for all data collection procedures, to ensure acceptability and consistency and reduce the possibility of errors. To ensure accuracy, the cooking pots and lids were marked with random numbers matching the type of maize meal.

The cooked porridge samples were served warm in small, clear, plastic bowls that had been covered with foil immediately after cooking to prevent loss of aroma to the atmosphere before the participants tasted the porridge. The tasting sets were as follows:

- $\quad$ white sifted unfortified maize meal versus white sifted fortified maize meal,

- hammer-mill white maize meal with fibre versus hammer-mill yellow maize meal with fibre,

- hammer-mill white maize meal without fibre versus hammer-mill yellow maize meal without fibre, and

- white sifted unfortified maize meal versus hammer-mill white maize meal without fibre versus white super maize meal.

Unless otherwise stipulated, all maize meal was produced by roller mill as this is what is mostly commercially practised.

At the start of the evaluation process the research team explained the purpose of the study and also gave a comprehensive explanation of the consent and evaluation forms. As soon as all the participants were clear about their role in the project, they washed their hands before beginning the tasting. The same procedure was followed in both villages.

Traditionally, maize meal porridge is moulded into a round shape and served in a dish. The acceptability of the texture of the maize meal porridge is then evaluated in three stages: first, 
when it is broken off from the mould by hand, second when it is moulded in the hand into a ball before dipping it into some gravy, and third when it is chewed in the mouth.

\subsection{Data collection for Phase II}

The main objective in Phase II was to obtain supportive information for the sensory evaluation tests in Phase I. Purposeful sampling and qualitative data collection and data analysis techniques were employed. Purposeful sampling for this study was directed at current and potential users of commercial roller-mill white and hammer-mill white and yellow maize meal. Focus group discussions were conducted to obtain detailed information about consumer attitudes, perceptions and practices involved in the consumption of maize meal porridge. The authors and interpreter conducted group interviews while standing, so that they could see the participants' facial expressions when they answered questions and could control the order of the interviews. All the participants were encouraged to explain their views without fear of intimidation. Those who held negative views of hammer-mill yellow maize meal were encouraged to elaborate why they did not like the porridge made from this kind of meal. The authors endeavoured to probe attitudes as well as uncover underlying feelings about the maize porridge. They encouraged the participants to give their honest opinions about the yellow maize porridge in particular. The focus group discussions were video-recorded and tape-recorded, and transcribed by the authors for verification immediately after Phase I before the collected data could be analysed. In other words, the multi-method approach to data collection was employed.

In Homu 14A Village the local pastor translated the proceedings. It is recognised that the use of an interpreter could lead to distorted answers from participants, if the interpreter gives the answers he thinks the researcher wants to hear (Green et al., 2004:55). In Mahlathi Village a female student currently following a Master's programme in the Department of Consumer Science at the University of Pretoria translated the proceedings. She knew the local language very well and understood the terminology of the study as well as the requirements of research of this kind.

Participants were each given a token of thanks for participating in the study in the form of five kilograms of commercially produced maize meal. The local pastor was paid a small fee for logistical assistance provided.

\subsection{Data analysis}

The data obtained from the sensory evaluation forms was cleaned and coded for analysis using SPSS version 12 for the one-way between-groups ANOVA with post-hoc tests (Pallant, 2005:214-15). For Phase II the data from the focus group discussions as well as from the field was transcribed verbatim into text form for narrative data analysis similar to reading and interpreting a poem or novel (Lieblich et al., 1998:170).

\section{Results and discussion}

Table 1 compares the results for white sifted unfortified maize meal and white sifted fortified maize meal. The porridge prepared from the fortified meal was preferred in terms of aroma (mean score 3.6), colour (3.6), visual consistency (3.5), hand feel (3.4), grittiness in mouth (3.4) and taste (3.3). The mean scores for the unfortified sample ranged from 2.8 to 2.9. In 
terms of colour, the fortified sample appeared whiter and thus appealed to the participants visually. Messer confirms that consumers prefer polished white grains with a whiter colour due to higher starch content (1989:10). The finer texture of the fortified sample was also found to be appealing. Brennan and Kuri observe that it is widely accepted that consumer like preference for a food product is mainly determined by their sensory perceptions (2002:65). In this case the taste of white sifted fortified maize meal porridge, combined with other sensory attributes considered in this study, had a positive effect.

The overall total score of 20.7 (translated into a 3.5 average) for white sifted fortified maize meal porridge indicated a range of 'like moderately' to 'like very much' for this sample. Even though both the fortified and unfortified samples elicited some degree of positive liking from the respondents in terms of all the attributes, the fortified sample was rated significantly higher than the unfortified one $(\mathrm{p}=\leq 0.01)$. This finding showed that white sifted fortified maize meal porridge was preferred to white sifted unfortified maize meal porridge (total score of 17.0 translated into a 1.4 average) for all the attributes investigated in the study.

Table 1: Comparison between white sifted unfortified and white sifted fortified

\begin{tabular}{|c|c|c|c|c|}
\hline \multirow[b]{2}{*}{ Attribute } & \multicolumn{2}{|c|}{ Mean scores $^{\text {a }}$} & \multirow[b]{2}{*}{$\begin{array}{l}\text { Significant } \\
\text { difference? }\end{array}$} & \multirow[b]{2}{*}{ Preferred sample } \\
\hline & $\begin{array}{l}\text { White sifted } \\
\text { unfortified }(n=48)\end{array}$ & $\begin{array}{l}\text { White sifted } \\
\text { fortified }(n=48)\end{array}$ & & \\
\hline Aroma $^{b}$ & $2.77 *$ & $3.35 *$ & Yes, $\mathrm{p} \leq 0.01$ & White sifted fortified \\
\hline Appearance: Colour ${ }^{\mathrm{b}}$ & $2.94 *$ & $3.63 *$ & Yes, $\mathrm{p} \leq 0.01$ & White sifted fortified \\
\hline Appearance: Consistency ${ }^{\mathrm{b}}$ & $2.90^{*}$ & $3.46^{*}$ & Yes, $\mathrm{p} \leq 0.01$ & White sifted fortified \\
\hline Texture: Feel (hand) ${ }^{b}$ & $2.90^{*}$ & $3.35^{*}$ & Yes, $\mathrm{p} \leq 0.05$ & White sifted fortified \\
\hline Texture: Grittiness (mouth) ${ }^{b}$ & $2.81 *$ & $3.38^{*}$ & Yes, $\mathrm{p} \leq 0.01$ & White sifted fortified \\
\hline Taste $^{b}$ & $2.81 *$ & $3.38^{*}$ & Yes, $\mathrm{p} \leq 0.01$ & White sifted fortified \\
\hline Total score $^{\mathrm{c}}$ & $16.96^{*}$ & $20.67 *$ & Yes, $\mathrm{p} \leq 0.01$ & White sifted fortified \\
\hline
\end{tabular}

${ }^{\mathrm{a}} 1=$ Dislike very much; $2=$ Dislike moderately; $2.5=$ Neutral; $3=$ Like moderately; $4=$ =Like very much

${ }^{\mathrm{b}}$ A mean attribute score of $>2.5$ indicates some level of liking, indicated by *

${ }^{\mathrm{c}}$ A total score of $>15$ indicates some level of liking, indicated by $*$

Table 2 compares the results for hammer-mill white maize meal with fibre and hammer-mill yellow maize meal with fibre. There was no high preference for either of the two porridge samples. The mean scores for the two types respectively were: aroma 2.4, 2.2; colour 2.1, 2.3; visual consistency 2.2, 2.2; hand feel 2.0, 2.2; grittiness in mouth 1.8, 2.0; and taste 1.9. These mean rating scores were generally close to 'dislike moderately'. Thus, both samples elicited some degree of dislike from the participants in terms of all the attributes. According to the ANOVA there was no significant difference between these two samples. This was confirmed by the results of the focus group discussions with the participants in Mahlathi village, who stated that they did not like the coarse or zakhomi hammer-mill yellow maize meal (zakhomi is the local term for the coarse maize meal, whether white or yellow), but that they liked the hammer-mill yellow maize meal without fibre because it had a fine texture. 
Table 2: Comparison between hammer-mill white with fibre and hammer-mill yellow with fibre

\begin{tabular}{|c|c|c|c|c|}
\hline \multirow[b]{2}{*}{ Attribute } & \multicolumn{2}{|c|}{ Mean scores $^{\mathrm{a}}$} & \multirow[b]{2}{*}{$\begin{array}{l}\text { Significant } \\
\text { difference? }\end{array}$} & \multirow[b]{2}{*}{$\begin{array}{c}\text { Preferred } \\
\text { sample }\end{array}$} \\
\hline & $\begin{array}{l}\text { Hammer-mill } \\
\text { white with fibre }(n=48)\end{array}$ & $\begin{array}{l}\text { Hammer-mill } \\
\text { yellow with fibre }(n=48)\end{array}$ & & \\
\hline Aroma $^{b}$ & 2.43 & 2.21 & No, $\mathrm{p}>0.1$ & None \\
\hline Appearance: Colour ${ }^{b}$ & 2.06 & 2.29 & No, $p>0.1$ & None \\
\hline Appearance: Consistency ${ }^{b}$ & 2.15 & 2.17 & No, $p>0.1$ & None \\
\hline Texture: Feel (hand) ${ }^{b}$ & 2.00 & 2.21 & No, $p>0.1$ & None \\
\hline Texture: Grittiness (mouth) ${ }^{b}$ & 1.79 & 1.98 & No, $p>0.1$ & None \\
\hline Taste $^{\mathrm{b}}$ & 1.85 & 2.02 & No, $p>0.1$ & None \\
\hline Total score $^{\mathrm{c}}$ & 12.08 & 12.83 & No, $p>0.1$ & None \\
\hline
\end{tabular}

${ }^{a} 1=$ Dislike very much; $2=$ Dislike moderately; $2.5=$ Neutral; $3=$ Like moderately; $4=$ Like very much

${ }^{\mathrm{b}}$ A mean attribute score of $>2.5$ indicates some level of liking, indicated by *

${ }^{c}$ A total score of $>15$ indicates some level of liking, indicated by *

Table 3 compares the results for hammer-mill white maize meal without fibre and hammermill yellow maize meal without fibre. The porridge prepared from the white maize sample was significantly preferred in terms of visual consistency (mean score 3.3) and hand feel (3.3).

Both maize meal porridge samples elicited some degree of preference from the participants in terms of all the attributes. It is important to note that when comparing hammer-mill white and yellow maize meal without fibre there was no significant difference in terms of participants' liking when it came to aroma, colour, grittiness in mouth, taste and the overall score.

It is important to note that it is not only the sensory attributes that are important, but also the preferences for particular combinations in different eating contexts, as explained by Conner and Armitage (2002:6). Even though the sensory tests did not reveal a preference for yellow maize meal, the participants in Homu 14A mentioned the presence of vitamin A in yellow maize meal as the reason for its potential acceptability. ${ }^{2}$

Table 3: Comparison between hammer-mill white without fibre and hammer-mill yellow without fibre

\begin{tabular}{|c|c|c|c|c|}
\hline \multirow[b]{2}{*}{ Attribute } & \multicolumn{2}{|c|}{ Mean scores $^{\mathrm{a}}$} & \multirow[b]{2}{*}{$\begin{array}{l}\text { Significant } \\
\text { difference? }\end{array}$} & \multirow[b]{2}{*}{ Preferred sample } \\
\hline & $\begin{array}{l}\text { Hammer-mill white } n \\
\text { fibre }(n=48)\end{array}$ & $\begin{array}{l}\text { Hammer-mill yellow } \\
\text { no fibre }(n=48)\end{array}$ & & \\
\hline Aroma $^{\mathrm{b}}$ & $3.13^{*}$ & $3.00 *$ & No, $p>0.1$ & None \\
\hline Appearance: Colour ${ }^{\mathrm{b}}$ & $3.33 *$ & $3.25 *$ & No, $p>0.1$ & None \\
\hline Appearance: Consistency ${ }^{b}$ & $3.31 *$ & $2.75^{*}$ & Yes, $\mathrm{p} \leq 0.05$ & Hammer-mill white no-fibre \\
\hline Texture: Feel (hand) ${ }^{b}$ & $3.29 *$ & $2.85^{*}$ & Yes, $p \leq 0.1$ & Hammer-mill white no-fibre \\
\hline Texture: Grittiness (mouth) ${ }^{b}$ & $3.00^{*}$ & $2.83^{*}$ & No, $p>0.1$ & None \\
\hline Taste $^{b}$ & $3.06^{*}$ & $2.98^{*}$ & No, $p>0.1$ & None \\
\hline Total score $^{\mathrm{c}}$ & $19.08^{*}$ & $17.67^{*}$ & No, $\mathrm{p}>0.1$ & None \\
\hline
\end{tabular}

a $1=$ Dislike very much; $2=$ Dislike moderately; $2.5=$ Neutral; $3=$ Like moderately; $4=$ Like very much

${ }^{\mathrm{b}}$ A mean attribute score of $>2.5$ indicates some level of liking, indicated by *

${ }^{\mathrm{c}}$ A total score of $>15$ indicates some level of liking, indicated by *

\footnotetext{
${ }^{2}$ The unexpected consumer awareness in this village about yellow maize meal and vitamin A can be traced to previous consumer research in the area pertaining to vitamin A rich maize ('Golden maize') during 2004 where members of the community were subjected to consumer education about the presence of vitamin A in certain yellow coloured food types and the advantages of adequate vitamin A intake. This is an encouraging indication that communities do appreciate and remember nutrition education, although not the purpose of the study.
} 
Table 4 compares the results for a) white sifted unfortified maize meal, b) white superfortified maize meal and c) hammer-mill white maize meal without fibre. There was a significantly higher preference for sample b), in terms of aroma (mean score 3.6), colour (3.8), visual consistency (3.5), hand feel (3.5), grittiness in mouth (3.4) and taste (3.5). The ratings for this sample were 'like moderately' and 'like very much,' whereas the ratings for samples a) and c) were generally closer to 'like moderately'. Even though the three samples elicited some degree of positive liking from the participants, in terms of all the attributes, sample b) was significantly preferred to samples a) and c) (p= $\leq 0.01$ and $p=\leq 0.05$, respectively). The ANOVA post-hoc test found no significant differences between samples a) and c).

Table 4: Comparison between white sifted unfortified, white super fortified and hammer-mill white no-fibre

\begin{tabular}{|c|c|c|c|c|c|}
\hline \multirow[t]{2}{*}{ Attribute } & \multicolumn{3}{|c|}{ Mean scores $^{\mathrm{a}}$} & \multirow{2}{*}{$\begin{array}{l}\text { Significant } \\
\text { difference? }\end{array}$} & \multirow{2}{*}{$\begin{array}{l}\text { Preferred } \\
\text { sample: }\end{array}$} \\
\hline & $\begin{array}{l}\text { a) White sifted unfortifie } \\
(n=48)\end{array}$ & $\begin{array}{l}\text { b) White super-fortified c } \\
(n=48)\end{array}$ & $\begin{array}{l}\text { c) Hammer-mill white } \\
\text { no fibre }(n=48)\end{array}$ & & \\
\hline Aroma $^{b}$ & $3.00^{*}$ & $3.56^{*}$ & $2.67 *$ & Yes, $\mathrm{p} \leq 0.01$ & White super fortified \\
\hline $\begin{array}{l}\text { Appearance: } \\
\text { Colour }{ }^{b}\end{array}$ & $3.02 *$ & $3.75^{*}$ & $3.04 *$ & Yes, $\mathrm{p} \leq 0.01$ & White super fortified \\
\hline $\begin{array}{l}\text { Appearance: } \\
\text { Consistency }{ }^{b}\end{array}$ & $2.88 *$ & $3.50 *$ & $3.06^{*}$ & Yes, $\mathrm{p} \leq 0.05$ & White super fortified \\
\hline $\begin{array}{l}\text { Texture: Feel } \\
\text { (hand) }{ }^{b}\end{array}$ & $2.83 *$ & $3.46^{*}$ & $3.19 *$ & Yes, $\mathrm{p} \leq 0.01$ & White super fortified \\
\hline $\begin{array}{l}\text { Texture: Grittiness } \\
\text { (mouth) }{ }^{b}\end{array}$ & $2.75 *$ & $3.40 *$ & $3,17 *$ & Yes, $\mathrm{p} \leq 0.01$ & White super fortified \\
\hline Taste $^{b}$ & $2.71 *$ & $3.50 *$ & $2.98 *$ & Yes, $\mathrm{p} \leq 0.01$ & White super fortified \\
\hline Total score ${ }^{\mathrm{c}}$ & $17.19^{*}$ & $21.17 *$ & $18.11^{*}$ & Yes, $\mathrm{p} \leq 0.01$ & White super fortified \\
\hline
\end{tabular}

a $1=$ Dislike very much; $2=$ Dislike moderately; $2.5=$ Neutral; $3=$ Like moderately; $4=$ Like very much

${ }^{\mathrm{b}}$ A mean attribute score of $>2.5$ indicates some level of liking, indicated by $*$

${ }^{c}$ A total score of $>15$ indicates some level of liking, indicated by *

The results of the focus group discussions were used to ascertain consumer perceptions of the maize meal. One finding was that price is an important consideration when purchasing maize meal. Participants in Homu 14A said that if the yellow commercial roller-mill and hammermill maize meal cost the same they would choose either - they had no particular preference, whereas participants in Mahlathi said that they would choose yellow maize meal from a commercial roller-mill for nutritional reasons. Homu 14A participants said that if yellow maize meal cost more than white they would still choose the yellow for its vitamin A content, whereas Mahlathi participants said they would choose the white because of the lower price. (The question was posed to respondents as a scenario where they faced a choice between yellow and white maize meal of the same milling type.)

When it came to reasons for not choosing yellow maize meal, the participants in both villages cited the non-availability of yellow maize meal (except in times of drought when it is supplied by the government for drought relief) as a limiting factor. Commercial roller-mill maize meal, however, is available all year round. According to Mela, familiar food products tend to be preferred to new or unfamiliar ones (1999:516). Availability of yellow maize meal throughout the year would lead to exposure and familiarity. The participants in this study expressed their wish that yellow maize meal be made available throughout the year instead of only during periods of drought. 
Table 5: Results of the focus group interviews

\begin{tabular}{|c|c|c|}
\hline \multirow[t]{2}{*}{ Questions } & \multicolumn{2}{|l|}{ Responses } \\
\hline & Ноти 14A $(n=21)$ & Mahlathi $(n=27)$ \\
\hline $\begin{array}{l}\text { Suppose this yellow maize is packed } \\
\text { like Iwisa would you buy it? Answer: Yes/No }\end{array}$ & Yes. & Yes. \\
\hline $\begin{array}{l}\text { You tasted the yellow maize here - how did } \\
\text { you like it? }\end{array}$ & $\begin{array}{l}\text { Did not like the taste, colour - } 4 \\
\text { Liked it - } 17\end{array}$ & $\begin{array}{l}\text { Yellow maize is bitter }-4 \\
\text { Yellow maize is nice }-32\end{array}$ \\
\hline What did you like about the yellow maize? & It contains Vitamin A. & $\begin{array}{l}\text { Yellow maize is rich with } \\
\text { things that make our bodies } \\
\text { healthy. }\end{array}$ \\
\hline $\begin{array}{l}\text { What else did you like about the yellow } \\
\text { maize? }\end{array}$ & Liked the aroma. & No response. \\
\hline $\begin{array}{l}\text { Let's look at the texture. We tasted the } \\
\text { texture twice. You know when we eat our } \\
\text { food we use our hands. How did the } \\
\text { yellow maize feel to you as you pressed it } \\
\text { between your fingers? }\end{array}$ & It's okay. & $\begin{array}{l}\text { Fine yellow maize meal is } \\
\text { okay, but we don't like the rough } \\
\text { maize meal. }\end{array}$ \\
\hline What about when you were chewing it? & Felt good about it. & It is fine. \\
\hline $\begin{array}{l}\text { If you are given a choice between } \\
\text { Iwisa/Ace and yellow maize meal, } \\
\text { which one would you choose? }\end{array}$ & Yellow maize meal. & $\begin{array}{l}\text { We like the fine yellow maize } \\
\text { Meal and ould buy it. }\end{array}$ \\
\hline $\begin{array}{l}\text { We want to know exactly what the people } \\
\text { in the Limpopo Province say about the } \\
\text { yellow maize meal. We want to know your } \\
\text { honest truth. }\end{array}$ & $\begin{array}{l}\text { People say that they don't } \\
\text { like the smell and colour. } \\
\text { We get it during drought. }\end{array}$ & $\begin{array}{l}\text { We like the yellow maize. We } \\
\text { usually get it during drought. } \\
\text { We wish we could get a } \\
\text { continuous supply. }\end{array}$ \\
\hline $\begin{array}{l}\text { If this yellow maize is sold in shops would } \\
\text { you buy it? Answer: Yes/No }\end{array}$ & Yes & Yes \\
\hline $\begin{array}{l}\text { Suppose the price of yellow maize meal is } \\
\text { up and for white maize meal the price is } \\
\text { low - which one would you buy? }\end{array}$ & $\begin{array}{l}\text { Will buy white maize meal - } 4 . \\
\text { Will buy yellow maize meal }-17\end{array}$ & Will buy white maize meal. \\
\hline So price can affect your choice? & Yes & Yes \\
\hline $\begin{array}{l}\text { Tell me, today we just looked at pap, but } \\
\text { what we want to see is if there are any } \\
\text { other occasions you can use this yellow } \\
\text { maize because we have established that } \\
\text { you are fine with fine yellow maize meal. }\end{array}$ & $\begin{array}{l}\text { Not sure other than using it } \\
\text { for pap. }\end{array}$ & $\begin{array}{l}\text { Any occasions as long as the } \\
\text { price is right. These include } \\
\text { weddings and cultural feasts. } \\
\text { The choice is determined by } \\
\text { the owner of the feast who has } \\
\text { a greater say in what can be } \\
\text { cooked. }\end{array}$ \\
\hline $\begin{array}{l}\text { Is there anything else you can tell us? In } \\
\text { what conditions do you normally get the } \\
\text { yellow maize meal? }\end{array}$ & $\begin{array}{l}\text { During drought it is supplied } \\
\text { to the area. }\end{array}$ & $\begin{array}{l}\text { During drought is when } \\
\text { we usually get it. }\end{array}$ \\
\hline $\begin{array}{l}\text { So there has been drought before in this } \\
\text { area - so you have been exposed to it } \\
\text { before? }\end{array}$ & $\begin{array}{l}\text { Yes. During good rains } \\
\text { yellow maize can't be found } \\
\text { anywhere in this area. }\end{array}$ & $\begin{array}{l}\text { In times of drought and after } \\
\text { the drought we wish we could } \\
\text { continue getting the yellow } \\
\text { maize meal. }\end{array}$ \\
\hline $\begin{array}{l}\text { In other words the failure is in the area } \\
\text { of manufacturers' thinking that if they } \\
\text { produce it people would not buy it/eat } \\
\text { it? Maybe that's why they are not } \\
\text { producing it? }\end{array}$ & $\begin{array}{l}\text { Note: This question was not } \\
\text { asked in Homu 14A. }\end{array}$ & $\begin{array}{l}\text { People would buy it as long as } \\
\text { the price is right. }\end{array}$ \\
\hline $\begin{array}{l}\text { Do any of you grow the yellow maize in } \\
\text { your gardens? Answer: Yes/No }\end{array}$ & $\begin{array}{l}\text { Yes }-6 \\
\text { No }-15 \\
\end{array}$ & $\begin{array}{l}\text { Some of us have grown it and } \\
\text { we like it on the cob. }\end{array}$ \\
\hline $\begin{array}{l}\text { What do you use for cooking it } \\
\text { (equipment and fuel)? }\end{array}$ & $\begin{array}{l}\text { Firewood and three-legged } \\
\text { Pots. }\end{array}$ & $\begin{array}{l}\text { Firewood and three-legged } \\
\text { Pots. }\end{array}$ \\
\hline
\end{tabular}




\section{Conclusion}

The findings of this study showed that consumer perceptions of the sensory attributes of maize meal porridge - aroma, colour, visual consistency, hand feel, grittiness in the mouth and taste - played a major role in the negative or positive overall acceptability of commercial roller-mill white maize meal, as well as hammer-mill white maize meal and yellow maize meal (with or without fibre) among Giyani female consumers in Limpopo Province, South Africa. The results suggest that fortificants added to the commercial roller-mill maize meal enhanced its overall acceptability. In this study the two maize meal types the participants liked best were white sifted fortified and white super-fortified. The whiter and finer the product, the more it was liked. Consumers prefer white polished grains because they cook more quickly and their taste and texture are 'more desirable than the darker ones' as Messer also observes (1989:10). This is despite the fact that white super-fortified maize meal is the most expensive maize meal type, followed by the special and then the sifted maize meal. The two hammer-mill varieties, white and yellow (both with fibre) were the types the participants disliked most, because of their coarse texture.

Another major finding of this study relates to fortified maize meal. The study revealed the positive acceptability of white sifted fortified and white super-fortified maize meal among female consumers in Giyani, Limpopo Province, South Africa. The participants chose the ratings 'like moderately' and 'like very much' for these fortified maize meal porridge samples. This preference for the fortified variety on a double-blind basis is quite surprising and unexpected, since a study conducted before the fortification legislation was implemented in South Africa (DoH, 2004:1) detected no effect on taste due to the addition of the fortification mix. Furthermore, the present study's finding that consumers preferred the fortified variety is in contrast to previous findings of research indicating some degree of consumer dislike of fortified maize meal, according to maize millers (Vermeulen, 2006:10).

Another important finding of this study relates to Giyani female participants' willingness to accept yellow maize meal, mainly for nutritional reasons. The participants in this study expressed their wish that yellow maize meal be made available throughout the year, instead of only during periods of drought (despite the fact that they did not reveal a sensory preference for yellow rather than white maize meal). The affordability of yellow maize meal, and the evidence that some consumers are aware of its superior nutritional value, means there could be an interesting business opportunity especially for small-scale farmers and millers in the area of study.

The South African milling industry is characterised by a high level of competition and there is a large range of maize meal products on the local market. It is recognised that by changing the availability and affordability of a food product it is possible to change its overall acceptability (Ritson \& Hutchins, 1995:22; Nestle et al., 1998:S56). Thus strategic research would be invaluable to both commercial and small-scale farmers, as it could provide them with useful information about which types of maize meal products are most likely to be acceptable to present and future consumers in a competitive market.

\section{Acknowledgements}

The authors wish to thank the National Research Foundation for funding the study, and Professor JF Kirsten, the project coordinator at the University of Pretoria, for his support. 


\section{References}

Batán, E, 2003. HarvestPlus research activities. www.harvestplus.org/maize.html Accessed 15 January 2009.

Brennan, CS \& Kuri, V, 2002. The relationship between sensory attributes, hidden attributes and price in influencing consumer perception of organic foods. In Powell, J, Davies, G, Fowler, S, Hovi, M, Lampkin, N, Lennartsson, M \& Padel, S (Eds), UK Organic Research 2002: Proceedings of the COR (Colloquium of Organic Researchers) Conference, pp. 65-8. Aberystwyth, UK.

Conner, M \& Armitage, CJ, 2002. The Social Psychology of Food. Open University, Philadelphia.

DoH (National Department of Health), 2004. Integrated Nutrition Programme: Issue 4. Government Printer, Pretoria.

DoH \& UNICEF South Africa (National Department of Health \& United Nations Children's Fund, South Africa), 2008. A reflection of the South African maize meal and wheat flour fortification programme (2004 to 2007).

www.unicef.org/southafrica/SAF_resources_wheatfortification.pdf Accessed 10 February 2011.

Furst, T, Connors, M, Bisogni, CA, Sobal, J \& Falk, LW, 1996. Food choice: A conceptual model of the process. Appetite 26(3), 247-65.

Green, C, Botha, P \& Schönfeldt, H, 2004. Needs assessment in a rural community on a commercial farm in South Africa. Journal of Family Ecology and Consumer Sciences, $32,46-59$.

Lawless, HT \& Heymann, H, 1998. Sensory Evaluation of Food: Principles and Practices. International Thomson, New York.

Lieblich, A, Tuval-Mashaiach, R \& Zilber, T, 1998. Narrative research: Reading, analysis and interpretation. Sage, London.

McCann, JC, 2005. Maize and Grace: Africa's Encounter with a New World Crop, 15002000. Harvard University Press, Cambridge.

Meiselman, HL, 1988. Consumer studies of food habits. In Piggott, JR (Ed.). Sensory Analysis of Foods, Second Edition. Elsevier Science, London.

Mela, DJ, 1999. Food choice and intake: The human factor. Proceedings of the Nutritional Society, the 3rd French-British Meeting on Nutrition, a joint meeting of the Nutrition Society, Association Française de Nutrition and Société de Nutrition et de Diététique de Langue Française, 30 September - 2 October , Nancy, France.

Messer, E, 1989. Methods for determinants of food intake. In Pelto, GH, Pelto, PJ \& Messer, E (Eds), Research Methods in Nutritional Anthropology. United Nations University Press, Japan.

Mqadi, L, 2005. Production function analysis of the sensitivity of maize production to climate change in South Africa. MSc Thesis, University of Pretoria, South Africa.

NDA (National Department of Agriculture), 1993. Agricultural Product Standards Act, 1993. Regulations relating to grading, packing and making maize products intended for sale in the Republic of South Africa. Government Printer, Pretoria.

NDA (National Department of Agriculture), 2006. Act no. 54 of 1972, 2006 Draft. Comments from industry for maize products: Foods, cosmetics and disinfectants. Government Printer, Pretoria.

Nestle, M, Birch, L Disogra, L, Drewnowski, A, Middleton, S, Sigman-Grant, M, Sobal, J, Winston, M \& Economos, C, 1998. Behavioural and social influences on food choice. Nutrition Review 56(5), S50-74.

Pallant, J, 2005. SPSS Survival Manual. Open University Press, Sydney. 
Reed, DB \& Schuster, E, 2002. Recipe checklist: A tool to aid development of recipes for audiences with limited resources. Journal of Extension (12), 1-8.

Resurrection, AVA, 1998. Consumer sensory testing for product development. Aspen, Maryland.

Ritson, C \& Hutchins, R, 1995. Supply and food availability. In Marshall, DW (Ed.), Food Choice and the Consumer. Blackie Academic and Professional, London.

Traub, LN \& Jayne, TS, 2004. The effects of market reform on maize marketing margins in South Africa: An empirical study. MSU (Michigan State University) International Development Working Paper, No. 5.

Vermeulen, H, 2006. Synthesis report on small-scale millers in South Africa. Prepared for the National Fortification Alliance and the National Fortification Programme, Pretoria. Unpublished Research Report November. 